\title{
In vitro efficacy of essential oils with different concentrations of 1,8-cineole against Rhipicephalus (Boophilus) microplus
}

\author{
Eficácia in vitro de óleos essenciais com diferentes concentraçôes de 1,8-cineol contra \\ Rhipicephalus (Boophilus) microplus \\ Ivanilza Moreira de Andrade ${ }^{4}$; João Avelar Magalhães ${ }^{1}$; Dhiéssica Morgana Alves Barros ${ }^{3}$ \\ ${ }^{1}$ Empresa Brasileira de Pesquisa Agropecuária - Embrapa Meio-Norte, Parnaíba, PI, Brasil \\ ${ }^{2}$ Empresa Brasileira de Pesquisa Agropecuária - Embrapa Agroindústria Tropical, Fortaleza, CE, Brasil \\ ${ }^{3}$ Universidade Federal do Maranhão - UFMA, Chapadinha, MA, Brasil \\ ${ }^{4}$ Universidade Federal do Piauí - UFPI, Parnaíba, PI, Brasil
}

Karina Neoob de Carvalho Castro ${ }^{1 *}$; Kirley Marques Canuto²; Edy de Sousa Brito²; Lívio Martins Costa-Júnior ${ }^{3}$;

Received November 22, 2017

Accepted February 15, 2018

\begin{abstract}
The aim of this study was to evaluate the acaricidal activity of essential oils from three species of plants with intermediary concentrations of 1,8-cineole against the tick species Rhipicephalus (Boophilus) microplus. For this purpose, five serial concentrations $(100.0,50.0,25.0,12.5,6.2 \mathrm{mg} / \mathrm{mL})$ of essential oils from Mesosphaerum suaveolens (L.) Kuntze, Ocimum gratissimum L. and Alpinia zerumbet (Pers.) B. L. Burtt \& R. M. Sm. were used on larval packet and adult immersion tests. The essential oils were analysed by gas chromatography-mass spectrometry (GC/MS) and gas chromatography-flame ionization detection (GC-FID), being detected 35.8, 24.7 and 24.0\% of 1.8-cineol in the oils of $M$. suaveolens, $O$. gratissimum and A. zerumbet, respectively. The lethal concentration $\left(\mathrm{LC}_{50}\right)$ of each oil for larvae and engorged females was calculated through Probit analysis. All essential oils showed high efficacy $(\geq 95.0 \%)$ on engorged females at the $100.0 \mathrm{mg} / \mathrm{mL}$ concentration. In regards to larvae, $O$. gratissimum $\left(\mathrm{LC}_{50}=11.9 \mathrm{mg} / \mathrm{mL}\right)$ was the most potent, followed by the $A$. zerumbet $\left(\mathrm{LC}_{50}=19.7 \mathrm{mg} / \mathrm{mL}\right)$ and the $M$. suaveolens $\left(\mathrm{LC}_{50}=51.6 \mathrm{mg} / \mathrm{mL}\right)$ essential oils. These results show that other compounds interfere with 1,8-cineole action.
\end{abstract}

Keywords: Acaricide, Alpinia zerumbet, Mesosphaerum suaveolens, Ocimum gratissimum, tick.

\section{Resumo}

O objetivo deste estudo foi avaliar a atividade acaricida de óleos essenciais de três espécies de plantas com concentraçóes intermediárias de 1,8-cineol contra o carrapato Rhipicephalus (Boophilus) microplus. Dessa forma, cinco concentraçôes diferentes $(100,0 ; 50,0 ; 25,0 ; 12,5 ; 6,2 \mathrm{mg} / \mathrm{mL})$ de óleos essenciais de Mesosphaerum suaveolens (L.) Kuntze, Ocimum gratissimum L. e Alpinia zerumbet (Pers.) B. L. Burtt \& R. M. Sm. foram avaliadas pelos testes de pacote de larvas e de imersão de adultos. Os óleos essenciais foram analisados pela cromatografia gasosa acoplada a espectometria de massa (GC/MS) e cromatografia gasosa acoplada a detector de ionização de chama (GC-FID), sendo detectados 35,8, 24,7 e 24,0\% de 1,8-cineol nos óleos de M. suaveolens, O. gratissimum e A. zerumbet, respectivamente. A concentração letal $\left(\mathrm{CL}_{50}\right)$ de cada óleo essencial para larvas e fêmeas ingurgitadas foi calculada por meio da análise de Probit. Todos os óleos essenciais na concentraçáo de $100,0 \mathrm{mg} / \mathrm{mL}$ apresentaram elevada eficácia $(\geq 95,0 \%)$ sobre fêmeas ingurgitadas. Com relação as larvas, o óleo essencial de O. gratissimum $\left(\mathrm{CL}_{50}=11,9 \mathrm{mg} / \mathrm{mL}\right)$ foi o mais potente, seguido pelos óleos de A. zerumbet $\left(\mathrm{LC}_{50}=19,7 \mathrm{mg} / \mathrm{mL}\right)$ e $M$. suaveolens $\left(\mathrm{LC}_{50}=51,6 \mathrm{mg} / \mathrm{mL}\right)$. Estes resultados demonstram que outros compostos interferem na eficácia de 1,8-cineol.

Palavras-chave: Acaricida, Alpinia zerumbet, Mesosphaerum suaveolens, Ocimum gratissimum, carrapato. 


\section{Introduction}

Ticks are parasites with economic importance for bovine and other domestic species in tropical and subtropical countries (MUHAMMAD et al., 2008). Blood spoliation, reduced weight gain, and transmission of Babesia spp. and Anaplasma marginale cause severe economic losses for livestock farmers (GRISI et al., 2014). The control of this parasite often requires the use of intense chemical acaricides that consequently select for resistant populations (RODRÍGUEZ-VIVAS et al., 2006). Acaricide resistance in ticks has become a major problem throughout the world and has been detected in Rhipicephalus (Boophilus) microplus against almost all the registered pesticides indicated for use against this parasite (CASTRO-JANER et al., 2009). Aditionally, the chemical control are costly and contaminate the environment with residues harmful to the hosts and also humans (FREITAS et al., 2005). On the other hand, substances obtained from plants have a low cost, few residual effects and a low incidence of generating resistance (ROSADO-AGUILAR et al., 2010). Essential oils contain a variety of volatile secondary metabolites that are known for their significant role in plant defence mechanisms (NAZZARO et al., 2013). These biodegradable, bioactive oils could be an alternative source for controlling insects, helminths and ticks (BAGAVAN et al., 2009). The terpenes in essential oils are an alternative means to control parasites (ANTHONY et al., 2005). The chemical variability in essential oils and the relationship among the compounds play important roles in the acaricidal activity (SOARES et al., 2016). It is not possible to affirm that the most abundant chemical compounds in an essential oil are responsible for the observed biological effects (GALINDO et al., 2010). Compounds found in small proportions can act as synergists with other minor or major molecules (SOARES et al., 2016). 1,8-cineole is an oxygenated monoterpene that acts on cell membranes, mainly through its hydrophobicity (HONÓRIO et al., 2015). This terpene exists, at varied concentrations, in several essential oils with acaricidal activity (PRATES et al., 1998; CHAGAS et al., 2002; SOARES et al., 2016). Studies comparing the essential oils of plants with intermediate concentrations of 1,8-cineole (24 to 35\%) are scarce, and understanding of how this compound participates in the activity of natural oils remains obscure.

The aim of the present study was to evaluate the acaricidal activity of essential oils, from aerial parts of two species of the Lamiaceae family (Mesosphaerum suaveolens, Ocimum gratissimum) and one of the Zingiberaceae family (Alpinia zerumbet), with intermediary concentrations of 1,8-cineole against the females and larvae of tick $R$. (B.) microplus.

\section{Materials and Methods}

\section{Plant material}

M. suaveolens is a plant native from Brazil where is known as "bamburral", while $O$. gratissimum and $A$. zerumbet are considered in this country as naturalized species and known, respectively, as "alfavaca-cravo" and "colônia". M. suaveolens and O. gratissimum were harvested during July 2013 (305'24.0”S, 4146’12.5”W) and June $2014\left(03^{\circ} 05^{\prime} 16.0^{\prime \prime S}, 41^{\circ} 47^{\prime} 01.5^{\prime \prime} \mathrm{W}\right)$, respectively, at the Unidade de Execução de Pesquisa da Embrapa Meio-Norte, in Parnaíba, Piauí, Brazil. The A. zerumbet was collected at Fazenda Tabuleiros II of the Anidro do Brasil Extraçôes S.A., Parnaíba, Piauí, in July 2011 (0301'27.5'S, 4144'53.5”W). Reference plant specimens were deposited in the herbarium of the Embrapa Recursos Genéticos e Biotecnologia under the registration numbers 81.097 (M. suaveolens), 92.497 (O. gratissimum) and 81.103 (A. zerumbet).

The essential oils were extracted at the Unidade de Execução de Pesquisa da Embrapa Meio-Norte, in Parnaíba, Piauí, from the aerial parts of $M$. suaveolens and from the leaves of $O$. gratissimum by hydro-distillation using a Clevenger apparatus. Nearly $2 \mathrm{~kg}$ of fresh plant was mixed with $3 \mathrm{~L}$ of water and boiled for $3 \mathrm{~h}$. A water steam distillation method was used to extract the essential oil from the leaves of $A$. zerumbet. The essential oils obtained were dried over anhydrous sodium sulphate, filtered, and stored at $4{ }^{\circ} \mathrm{C}$ until being tested and analysed at the Embrapa Agroindústria Tropical, in Fortaleza, Ceará, by Gas Chromatography Mass Spectrometry (GC-MS) and Flame Ionization Detector (GC-FID) for determination of their chemical composition (CASTRO et al., 2016).

\section{Essential oil analysis}

The GC-MS analyses were carried out on an Agilent 7890B-GC/5977A-MS instrument equipped with a nonpolar VF-5MS fused silica capillary column $(30 \mathrm{~m} \times 0.25 \mathrm{~mm}$ ID, $0.25 \mu \mathrm{m}$ film thickness) utilizing a split ratio of 1:30 and helium at $1.5 \mathrm{~mL} \mathrm{~min}^{-1}$ as the carrier gas. The injector temperature and detector temperature were set at $250{ }^{\circ} \mathrm{C}$. The oven temperature was raised from 70 to $180{ }^{\circ} \mathrm{C}$ at $4{ }^{\circ} \mathrm{C} \mathrm{min}$ mi $^{-1}$ and afterwards to $250{ }^{\circ} \mathrm{C}$ at $10{ }^{\circ} \mathrm{C} \mathrm{min}^{-1}$. Mass spectra were recorded in a range of mass-to-charge ratio $(\mathrm{m} / \mathrm{z})$ between 30 and 450 . GC-FID analyses were performed on a Shimadzu GC-2010 Plus chromatograph in the same aforementioned chromatographic conditions except for the carrier gas (hydrogen). The retention indices were determined by the injection of a mixture of $\mathrm{C}_{7}-\mathrm{C}_{30}$ homologous n-alkanes (Sigma, St. Louis, MO). The identification of the volatile compounds was achieved through the comparison of the mass spectra recorded with those provided by the spectrometer database (NIST 02-287,324 compounds) along with the retention indices and mass spectra of the literature (ADAMS, 2007; NIST, 2011). The relative content of each constituent was quantified as the normalized peak area detected in the GC-FID chromatogram and expressed as a percentage.

\section{Preparation of the dilutions}

For each oil, solutions were prepared at concentrations of $6.2,12.5,25.0,50.0$ and $100.0 \mathrm{mg} / \mathrm{mL}$. The negative controls consisted of the solvents used in the essential oil dilutions, which were $50 \%$ ethanol and $3 \%$ Tween 80 . As the positive control, a mixture of $0.18 \mathrm{mg} / \mathrm{mL}$ cypermethrin, $0.30 \mathrm{mg} / \mathrm{mL}$ chlorpyrifos, and $0.012 \mathrm{mg} / \mathrm{mL}$ citronellal (Colosso ${ }^{\circledR}$, Ouro Fino, São Paulo) was used. This solution was diluted to a $0.125 \%$ concentration in ultrapure water. All tests were replicated three times. 


\section{Tick preparation}

Engorged $R$. (B.) microplus females were collected from naturally infected cattle, washed with water and then dried with paper towels. A number of the engorged females were kept in an incubator and maintained at $27 \pm 1^{\circ} \mathrm{C}$ with relative humidity $(\mathrm{RH})$ $\geq 80 \%$ until oviposition of the larvae (for the larval packet test) was finished. Acaricide tests had been performed previously that demonstrated the resistance of the tick population to amidinic and pyrethroid compounds. The analyses with ticks were performed at the Unidade de Execuçáo de Pesquisa da Embrapa Meio-Norte, in Parnaíba, Piauí.

\section{Larval packet test}

The larval packet test was used following the method of Stone $\&$ Haydock (1962) and the Food and Agriculture Organization of the United Nations (FAO, 1971). Approximately one hundred larvae, 14-21 days old, were placed between two filter papers $(2 \times 2 \mathrm{~cm})$ impregnated with the appropriate essential oil and concentration, to form a sandwich. Each "sandwich" was introduced to a filter paper envelope and then sealed, identified, and incubated at $27^{\circ} \mathrm{C}$ with $\mathrm{RH} \geq 80 \%$ for $24 \mathrm{~h}$ (LEITE, 1988). After this time, larvae, alive and dead, were counted. Ticks showing no movement were considered dead. Each treatment was performed in triplicate. Mortality was calculated from the average of three replicates:

$$
\text { Corrected mortality }(\%)=\frac{\left(\begin{array}{l}
\% \text { test mortality }- \\
\% \text { control mortality }
\end{array}\right) \times 100}{100-\% \text { control mortality }}
$$

\section{Adult immersion test}

The adult immersion test of engorged $R$. (B.) microplus females was conducted according to the method described by Drummond et al. (1973). Engorged females were selected based on their mobility, body integrity, and size $(\geq 4.5 \mathrm{~mm})$. The females were then weighed and distributed into ten-specimen groups with similar weights. The weight of engorged females ranged between 170 and $210 \mathrm{mg}$ (BENNETT, 1974). Each group of females was immersed in their appropriate treatment solution for 5 minutes, dried with paper towels, and stored in a chamber at $27^{\circ} \mathrm{C}$ and $\mathrm{RH} \geq 80 \%$ for 18 days. After that period, the egg mass was weighed, transferred to adapted syringes, and incubated for 20 days $\left(27^{\circ} \mathrm{C}\right.$ and $\left.\mathrm{RH} \geq 80 \%\right)$. The experiment was performed with three replicates for each treatment.

Hatchability was estimated from the average number of eggs and larvae. The egg production index (EPI), oviposition reduction $(\mathrm{OR})$, reproductive efficiency (RE), and product effectiveness (PE) were calculated according to the following formulas: $\mathrm{EPI}=$ (weight of eggs/weight of engorged females $) \times 100$ (BENNETT, 1974); OR = ((control EPI - treated EPI $) /$ control EPI $)$ $\times 100$ (ROULSTON et al., 1968); RE = (Egg mass weight $\times \%$ of eclosion/weight of the mass of females $) \times 20,000$; and PE $=$ (control $\mathrm{RE}$ - treated RE)/(control RE $\times 100)(\mathrm{DRUMMOND}$ et al., 1973).

This study was performed with the approval of the Ethics Committee for Animal Experimentation of the Universidade Federal do Maranháo under approval number 23115018061.

\section{Statistical analysis}

The lethal concentration of the essential oil for $50 \%$ of the population $\left(\mathrm{LC}_{50}\right.$ ) of larvae and engorged females was calculated through Probit analysis with GraphPad Prism 7.0 software. An essential oil was considered to be significantly different from another one when the $95 \%$ confidence intervals of the calculated $\mathrm{LC}_{50}$ did not overlap (RODITAKIS et al., 2005). The difference between the concentrations of mortality against larvae and engorged females and the index RO, hatchability and EP were analysed by a paired t-test $(\mathrm{p}<0.05)$.

\section{Results and Discussion}

The chemical compositions of the tested essential oil samples are presented in Table 1 . The chemical composition of the $A$. zerumbet essential oil was previously determined by Castro et al. (2016). Twenty-three, nineteen and twenty-one components were identified in the essential oils from $M$. suaveolens, O. gratissimum and $A$. zerumbet, respectively, representing over $96 \%$ of their total compounds.

The basic components of all the oils were monoterpenes and sesquiterpenes, except for the O. gratissimum essential oil, which contained a short-chain alcohol (3-hexen-1-ol) and a phenylpropanoid. This latter compound (eugenol) was the major component of the essential oil, approximately $53 \%$, followed by 1,8 -cineole (24.7\%). The most abundant components found in the M. suaveolens essential oil were 1,8-cineole (35.8\%) and sabinene (19.6\%), while the A. zerumbet essential oil presented p-cymene (32.7\%), 1,8-cineole (24.0\%) and terpinen-4-ol (20.2\%) as the main components (Table 1 ).

One of the major constituents in all three species of essential oils was 1,8-cineole. This pure monoterpene caused $100 \%$ lethality in $R$. (B.) microplus larvae (PRATES et al., 1998). On the other hand, 1,8-cineole extracted from Ocimum species and used at a $2 \%$ concentration was not an effective acaricidal against $R$. (B.) microplus (HÜE et al., 2015). This latter result may be due to a low concentration of this compound in the evaluated solution.

1,8-Cineole is present in several essential oils that do and do not have activity against $R$. (B.) microplus. At a concentration of $10.6 \%$ in the Melinis minutiflora essential oil and of $85.8 \%$ in Eucalyptus globulus essential oil, the acaricidal action of 1,8-cineole was maximum (100\%) on larvae of $R$. (B.) microplus (PRATES et al., 1998; CHAGAS et al., 2002). A change in the major components of essential oils does not always lead to significate changes in their action on ticks. Minor components of the oil mixture are just as important as major constituents, and their effects must be considered as a reflection of the interaction of all the constituents (AKHTAR et al., 2012). As an example, the essential oil from $O$. gratissimum contains $24.7 \%$ of 1,8 -cineole 
Table 1. Comparative chemical composition of essential oils from Mesosphaerum suaveolens, Ocimum gratissimum and Alpinia zerumbet.

\begin{tabular}{|c|c|c|c|c|c|}
\hline \multirow{2}{*}{ Compounds } & \multirow{2}{*}{$\mathbf{K I}^{\mathbf{a}}$} & \multirow{2}{*}{$\mathrm{KI}_{\text {lit }}^{\mathrm{b}}$} & \multicolumn{3}{|c|}{ Relative percentages $(\%)^{c}$} \\
\hline & & & M. suaveolens & O. gratissimum & ${ }^{*}$ A. zerumbet \\
\hline 3-hexen-1-ol & 855 & 853 & & 0.38 & \\
\hline á-thujene & 934 & 930 & 0.43 & & 2.57 \\
\hline á-pinene & 941 & 939 & 3.03 & 0.83 & 1.54 \\
\hline Camphene & 960 & 954 & 0.31 & & 0.29 \\
\hline Sabinene & 979 & 975 & 19.61 & 0.67 & 5.02 \\
\hline â-pinene & 984 & 979 & 7.59 & 2.11 & 2.37 \\
\hline Myrcene & 993 & 990 & 0.59 & 0.56 & 0.66 \\
\hline ä-3-carene & 1019 & 1011 & 1.46 & & \\
\hline á-terpinene & 1024 & 1017 & 0.36 & & 0.06 \\
\hline p-cymene & 1034 & 1024 & 1.65 & & 32.72 \\
\hline Limonene & 1037 & 1029 & 2.79 & & 2.09 \\
\hline 1,8-cineole & 1038 & 1031 & 35.77 & 24.68 & 24.05 \\
\hline Cis-ocimene & 1040 & 1037 & & 5.30 & \\
\hline Trans-ocimene & 1051 & 1050 & & 0.34 & \\
\hline ã-terpinene & 1063 & 1059 & 0.69 & 0.14 & 0.68 \\
\hline Trans-4-thujanol & 1075 & 1070 & & & 0.15 \\
\hline á-terpinolene & 1095 & 1088 & 2.80 & & 0.28 \\
\hline Linalol & 1101 & 1096 & 0.24 & 0.43 & \\
\hline Cis-â-terpineol & 1102 & & & & 1.01 \\
\hline Fenchol & 1122 & 1116 & & & 2.73 \\
\hline Cis-p-menth-2-en-1-ol & 1129 & 1121 & & & 0.65 \\
\hline Citronellal & 1156 & 1153 & 0.48 & & \\
\hline Terpinen-4-ol & 1181 & 1177 & 1.77 & 0.31 & 20.23 \\
\hline á-terpineol & 1193 & 1188 & & 0.73 & \\
\hline Trans-piperitol & 1214 & & & & 0.23 \\
\hline Bornyl acetate & 1293 & 1285 & & & 0.17 \\
\hline Eugenol & 1362 & 1359 & & 52.99 & \\
\hline Bourbonene & 1393 & 1388 & 0.31 & & \\
\hline â-elemene & 1398 & 1390 & 0.44 & & \\
\hline â-caryophyllene & 1423 & 1408 & 3.13 & 2.72 & 0.24 \\
\hline á-caryophyllene & 1458 & 1454 & & 0.36 & \\
\hline Germacrene D & 1484 & 1485 & 3.00 & 1.01 & \\
\hline â-selinene & 1489 & 1490 & & 4.22 & \\
\hline á-selinene & 1497 & 1498 & & 1.50 & \\
\hline Bicyclogermacrene & 1505 & 1500 & 7.80 & & \\
\hline 7-epi-á-selinene & 1521 & 1522 & & 0.27 & \\
\hline Spathulenol & 1587 & 1578 & 1.05 & & \\
\hline Caryophyllene oxide & 1593 & 1593 & 0.33 & & 1.70 \\
\hline Total & & & 96.25 & 99.55 & 99.44 \\
\hline
\end{tabular}

${ }^{a}$ KI: Kovats index displayed by compounds in RTX column; ${ }^{b} \mathrm{KI}_{\mathrm{lit}}$ : Literature data (ADAMS, 2007; NIST, 2011); 'Peak relative areas determined in the GC-FID chromatogram; *Data reported by Castro et al. (2016).

and presents high acaricidal activity on tick females and larvae (Table 2 and 3), however Ocimum canum essential oil, which is $70.2 \%$ 1,8-cineole, does not show any action on $R$. (B.) microplus (HÜE et al., 2015). It is possible that the identified components of essential oils could have antagonistic activity towards each other and consequently reduce the acaricidal action of other major compounds (SOARES et al., 2016).

All three essential oils tested in this study exhibited significant anti-tick activity against $R$. (B.) microplus. The $M$. suaveolens essential oil had significantly lower activity $\left(\mathrm{LC}_{50}=51.6 \mathrm{mg} / \mathrm{mL}\right)$ on larvae than both the $O$. gratissimum $\left(\mathrm{LC}_{50}=11.9 \mathrm{mg} / \mathrm{mL}\right)$ and the $A$. zerumbet $\left(\mathrm{LC}_{50}=19.7 \mathrm{mg} \mathrm{mL}^{-1}\right)$ essential oils. Moreover it was significantly lower $\left(\mathrm{LC}_{50}=31.3 \mathrm{mg} \mathrm{mL}^{-1}\right)$ than the $A$. zerumbet $\left(\mathrm{LC}_{50}=20.7 \mathrm{mg} \mathrm{mL}^{-1}\right.$ ) essential oil on engorged females (Table 4). The presence of a probable antagonistic compound to 1,8-cineole in the $M$. suaveolens essential oil could justify the reduced larval mortality in relation to the other species. Essential oils has complex mixtures of chemical constituents that may act together synergistically or antagonistically contributing to control of ticks by different action modes (SOARES et al., 2016). 
The action of the three essential oils was dose-dependent in the two different life stages of the tick. Tables 2 and 3 present the percentages obtained for in vitro action of the three essential oils on the larvae (mortality) and engorged females (egg production index, reduction in oviposition, eggs hatched and efficiency).

In addition to having the lowest $\mathrm{LC}_{50}$ among the essential oils tested in the present study, the $M$. suaveolens essential oil, at $100 \mathrm{mg} / \mathrm{mL}$, reduced larvae mortality to $87.7 \%$ and had $100 \%$ efficacy on engorged females. In Laos, the $M$. suaveolens essential oil is a strong repellent against the tick Ixodes ricinus. This oil also has 1,8-cineole (16.5-46.6\%) and sabinene (15.0-21.2\%) as major compounds, which vary in concentration according to the geographic origin of the plants (ASHITANI et al., 2015). Furthermore, the chemical differences in the genotypes of the plant may influence the acaricidal activity against $R$. (B.) microplus (SOARES et al., 2016).

Table 2. Efficacy of essential oils from Mesosphaerum suaveolens, Ocimum gratissimum and Alpinia zerumbet on larvae of Rhipicephalus (Boophilus) microplus.

\begin{tabular}{cccc}
\hline $\begin{array}{c}\text { Concentration } \\
(\mathbf{m g} / \mathbf{m L})\end{array}$ & $\begin{array}{c}\text { M. suaveolens } \\
(\%)\end{array}$ & $\begin{array}{c}\text { O. gratissimum } \\
(\mathbf{\%})\end{array}$ & $\begin{array}{c}\text { A. zerumbet } \\
(\%)\end{array}$ \\
\hline Negative control & $0.5 \pm 0.5$ & $1.8 \pm 0.5$ & $0.5 \pm 0.9$ \\
$6.2(0.62 \%)$ & $0.4 \pm 0.6$ & $20.8 \pm 6.9$ & $0.5 \pm 0.8$ \\
$12.5(1.25 \%)$ & $0.4 \pm 0.7$ & $65.6 \pm 6.0$ & $0.9 \pm 1.6$ \\
$25.0(2.5 \%)$ & $9.6 \pm 7.6$ & $91.6 \pm 8.2$ & $94.4 \pm 7.0$ \\
$50.0(5 \%)$ & $39.2 \pm 9.7$ & $98.3 \pm 2.9$ & $100.0 \pm 0.0$ \\
$100.0(10 \%)$ & $87.7 \pm 3.5$ & $99.4 \pm 1.1$ & $100.0 \pm 0.0$ \\
Positive control & $100.0 \pm 0.0$ & $100.0 \pm 0.0$ & $100.0 \pm 0.0$ \\
\hline
\end{tabular}

Negative control $=50 \%$ ethanol $+3 \%$ Tween 80 ; Positive control $=0.18 \mathrm{mg} / \mathrm{mL}$ cypermethrin, $0.30 \mathrm{mg} / \mathrm{mL}$ chlorpyrifos, and $0.012 \mathrm{mg} / \mathrm{mL}$ citronellal.
The $O$. gratissimum essential oil tested in our study induced high mortality $(98.3 \%)$ on $R$. (B.) microplus larvae at a concentration of $5.0 \%(50 \mathrm{mg} / \mathrm{mL})$ (Table 2). Nevertheless, the essential oil from this plant (undisclosed chemical composition) collected in the Minas Gerais state (Brazil) caused only $74.6 \%$ of larvae mortality, even though its concentration was five times higher (25\%) (HOCAYEN \& PIMENTA, 2013). Ocimum is also known for its large chemotypic variation depending on the geographical origin (HILTUNEN \& HOLM, 1999). Environmental factors could support one expressive variation in chemical composition and consequently alter the oil's acaricidal efficacy (HÜE et al., 2015). In regards to engorged females, the $O$. gratissimum essential oil of this study at $10 \%(100 \mathrm{mg} / \mathrm{mL})$ achieved $99.9 \%$ efficacy.

The proportion of the major compounds of the $A$. zerumbet essential oil (p-cymene, 1,8-cineole, 4-terpineol) in this study are similar to those reported for this species that greatly inhibited $(81.2 \%)$ the egg hatch of the parasite Haemonchus contortus (MACEDO et al., 2013). The larvicidal effect of essential oils from A. zerumbet and O. gratissimum $(100 \mathrm{mg} / \mathrm{mL})$ was similar to that induced by chemical acaricide $(0.18 \mathrm{mg} / \mathrm{mL}$ cypermethrin, $0.30 \mathrm{mg} / \mathrm{mL}$ chlorpyrifos, and $0.012 \mathrm{mg} / \mathrm{mL}$ citronellal).

In engorged females, the three essential oils, at $100 \mathrm{mg} / \mathrm{mL}$, greatly reduced oviposition (ranging from 95.5 to $100.0 \%$ ) and hatchability ( 0.0 a $0.8 \%$ ), exhibiting an average efficiency that ranged from 99.9 to $100 \%$, but there was no significant difference among them at this concentration $(\mathrm{p}>0.05)$. This action on engorged females was similar to that induced by the positive control (Table 3).

The susceptibility of adult Rhipicephalus spp. to essential oils generally appears to be substantially lower than that of the larvae (ELLSE \& WALL, 2014). As an example, in this study, the essential oils from $A$. zerumbet and $O$. gratissimum obtained an

Table 3. Egg production index (EPI), reduction in oviposition (RO), eggs hatched and efficiency (EP) of essential oil from Mesosphaerum suaveolens, Ocimum gratissimum and Alpinia zerumbet on engorged females of Rhipicephalus (Boophilus) microplus.

\begin{tabular}{|c|c|c|c|c|c|}
\hline & $\mathrm{mg} / \mathrm{mL}$ & EPI & RO (\%) & Eggs hatched (\%) & EP (\%) \\
\hline Negative control & - & $47.2 \pm 7.4$ & - & $83.4 \pm 7.9$ & - \\
\hline \multirow[t]{5}{*}{ M. suaveolens } & 6.2 & $51.3 \pm 2.5$ & $4.3 \pm 7.5$ & $72.1 \pm 2.3$ & $9.4 \pm 14.7$ \\
\hline & 12.5 & $40.2 \pm 5.2$ & $15.3 \pm 15.6$ & $73.8 \pm 2.7$ & $23.4 \pm 14.4$ \\
\hline & 25.0 & $31.9 \pm 7.6$ & $32.8 \pm 8.8$ & $75.9 \pm 5.8$ & $39.0 \pm 7.1$ \\
\hline & 50.0 & $11.8 \pm 1.6$ & $74.6 \pm 5.8$ & $68.0 \pm 9.3$ & $79.3 \pm 5.0$ \\
\hline & 100.0 & $0.0 \pm 0.0$ & $100.0 \pm 0.0$ & $0.0 \pm 0.0$ & $100.0 \pm 0.0$ \\
\hline \multirow[t]{5}{*}{ O. gratissimum } & 6.2 & $45.4 \pm 3.3$ & $10.8 \pm 7.8$ & $70.6 \pm 13.1$ & $22.6 \pm 21.7$ \\
\hline & 12.5 & $42.8 \pm 4.7$ & $17.7 \pm 8.3$ & $66.2 \pm 2.5$ & $32.2 \pm 12.5$ \\
\hline & 25.0 & $34.2 \pm 9.1$ & $34.2 \pm 17.8$ & $56.8 \pm 10.8$ & $51.6 \pm 24.4$ \\
\hline & 50.0 & $19.7 \pm 8.0$ & $62.2 \pm 15.3$ & $24.1 \pm 12.7$ & $90.1 \pm 4.9$ \\
\hline & 100.0 & $2.3 \pm 2.6$ & $95.5 \pm 5.2$ & $0.8 \pm 1.3$ & $99.9 \pm 0.2$ \\
\hline \multirow[t]{5}{*}{ A. zerumbet } & 6.2 & $50.3 \pm 2.0$ & $1.9 \pm 2.3$ & $87.6 \pm 1.7$ & $7.2 \pm 6.6$ \\
\hline & 12.5 & $48.7 \pm 3.4$ & $2.5 \pm 2.7$ & $68.9 \pm 5.1$ & $29.0 \pm 6.6$ \\
\hline & 25.0 & $33.3 \pm 5.6$ & $33.5 \pm 7.4$ & $52.2 \pm 4.3$ & $63.2 \pm 6.6$ \\
\hline & 50.0 & $9.0 \pm 8.3$ & $82.1 \pm 15.8$ & $31.9 \pm 12.9$ & $92.6 \pm 6.7$ \\
\hline & 100.0 & $0.8 \pm 1.4$ & $98.2 \pm 3.1$ & $0.0 \pm 0.0$ & $100.0 \pm 0.0$ \\
\hline Positive control & & $1.7 \pm 2.8$ & $96.1 \pm 6.5$ & $11.1 \pm 18.4$ & $98.6 \pm 2.4$ \\
\hline
\end{tabular}

Negative control $=50 \%$ ethanol $+3 \%$ tween 80 ; Positive control $=0.18 \mathrm{mg} / \mathrm{mL}$ cypermethrin, $0.30 \mathrm{mg} / \mathrm{mL}$ chlorpyrifos, and $0.012 \mathrm{mg} / \mathrm{mL}$ citronellal. EPI $=$ egg production index; $\mathrm{RO}=$ reduction in oviposition; $\mathrm{EP}=$ efficiency of the product. 
Table 4. Lethal concentration of the essential oils from Mesosphaerum suaveolens, Ocimum gratissimum and Alpinia zerumbet against Rhipicephalus (Boophilus) microplus larvae and engorged females.

\begin{tabular}{lccc}
\hline Treatment & $\mathbf{L C}_{\mathbf{5 0}}(\mathbf{m g} / \mathbf{m L})$ & $\mathbf{C L}$ 95\% & $\mathbf{R}^{\mathbf{2}}$ \\
\hline Larvae & & & \\
M. suaveolens & $51.6^{\mathrm{c}}$ & $47.7-55.9$ & 0.97 \\
O. gratissimum & $11.9^{\mathrm{a}}$ & $11.0-13.0$ & 0.97 \\
A. zerumbet & $19.7^{\mathrm{b}}$ & $15.7-24.6$ & 0.99 \\
Engorged female & & & \\
M. suaveolens & $31.3^{\mathrm{b}}$ & $26.4-37.0$ & 0.93 \\
O. gratissimum & $28.4^{\mathrm{ab}}$ & $21.9-36.9$ & 0.85 \\
A. zerumbet & $20.7^{\mathrm{a}}$ & $18.8-22.8$ & 0.98 \\
\hline
\end{tabular}

$\mathrm{LC}_{50}=$ Lethal concentration $50 \%(\mathrm{mg} / \mathrm{mL}) R$. (Boophilus) microplus larvae or engorged females; $\mathrm{CL}=95 \%$ Confidence limit; $\mathrm{R}^{2}=$ Regression coefficient. Values followed by the same letters do not differ significantly, alpha $=5 \%$.

efficacy value of 99.9 to $100.0 \%$ against engorged females when used at a concentration of $100 \mathrm{mg} / \mathrm{mL}$, while similar values of larvae mortality (98.3 to $100 \%)$ were observed at concentrations $50 \%$ lower $(50 \mathrm{mg} / \mathrm{mL})$. However, opposite results were obtained when the M. suaveolens essential oil was evaluated, which had a higher activity against the engorged females $(100 \%)$ than the R. (B.) microplus larvae $(87.7 \%)$ at $100 \mathrm{mg} / \mathrm{mL}$. This variation in activity is probably related to each oil's unique mode of action against the specific life stage of the tick (SOARES et al., 2016).

In this study, the first point of contact of the essential oils is the cuticle of engorged females and larvae (DRUMMOND et al., 1973; LEITE, 1988). When crossing the integument of the tick, the substances can reach the haemolymph and act on the internal organs (REMEDIO et al., 2015). Certain substances may affect the salivary glands, consequently impairing the process of concentrating ingested blood and thus hindering the effective absorption of nutrients by the ticks (REMEDIO et al., 2016). There is an important correlation between the tick's digestive and reproductive system and, thus, digestive problems can damage their reproductive capacity (REMEDIO et al., 2016). The cattle tick has a high biotic potential (OLIVER, 1989), therefore products and substances that act on their reproductive system are of great interest in the control of these populations (OLIVEIRA et al., 2016). The ovary of $R$. (B.) microplus consists of an epithelial cell wall and oocytes (germ cells) that are at different developmental stages (OLIVEIRA et al., 2005). An injury to the oocytes decreases the female's capacity to produce viable eggs and descendents. A high reduction in oviposition and hatchability resulted in a high efficiency of the essential oils from $A$. zerumbet, $O$. gratissimum and $M$. suaveolens, at $100 \mathrm{mg} / \mathrm{mL}$, against engorged females of R. (B.) microplus (Table 3).

Functional impairment of the reproductive system of ticks is usually a consequence of significant morphophysiological alterations that have been detected in females exposed to andiroba oil (Carapa guianensis Aubl.) (VENDRAMINI et al., 2012) and to neem oil (Azadirachta indica A. Juss.) (REMEDIO et al., 2015). Some extracts of plants, when used to treat females in the beginning or in the middle of the engorgement process, are more efficient in the control of this parasite. Thus, the substances can penetrate the cells more easily and act in their interior (OLIVEIRA et al., 2016). It is reasonable to assume that the efficacy of the three essential oils in this study would be higher in early stages of engorged females even at lower concentrations.

The tick has a central nervous system that is known as synganglion (ROMA et al., 2012). Neural morphological damage resulting from a degenerative process would be capable of affecting nerve impulse transmission in ticks, impairing locomotion and feeding mechanisms. Some oils that originate from plants promote such morphological changes (ROMA et al., 2013). Neurotoxic action can be caused also by oils and compounds that inhibit acetylcholinesterase (AChE), an enzyme essential for the transmission of action potentials (MILLS et al., 2004; LÓPEZ \& PASCUAL-VILLALOBOS, 2010). The monoterpenoid 1,8-cineole inhibit AChE activity from insects (ABDELGALEIL et al., 2009) and is one of the main compounds of the three essential oils evaluated in this study whose efficacy on larvae and females was demonstrated. This result indicates the possible action of these three essential oils on the nervous system of the tick.

The possibility of reduction in risks of contamination of food and the environment by alternative products is a worldwide desire (ADENUBI et al., 2016). However, more studies should be performed to develop formulations that protect this oils and your active compounds from environmental degradation. These results, demonstrated that the essential oils evaluated may be a viable alternatives to synthetic acaricides.

\section{Conclusion}

All three essential oils evaluated show a high efficacy against engorged females at their highest concentration and produced similar results to those induced by chemical acaricide. In regards to larvae, O. gratissimum was the most efficient, followed by the $A$. zerumbet and the $M$. suaveolens essential oils. Our results indicated that minor compounds interfere on the action of 1,8-cineole present in essential oils.

\section{References}

Abdelgaleil SAM, Mohamed MIE, Badawy MEI, El-arami SAA. Fumigant and contact toxicities of monoterpenes to Sitophilus oryzae (L.) and Tribolium castaneum (Herbst) and their inhibitory effects on acetylcholinesterase activity. J Chem Ecol 2009; 35(5): 518-525. PMid:19412756. http:// dx.doi.org/10.1007/s10886-009-9635-3.

Adams RP. Identification of essential oil components by gas chromatography/ mass spectroscopy. 4th ed. Illinois: Allured Publishing Corporation; 2007.

Adenubi OT, Fasina FO, McGaw LJ, Eloff JN, Naidoo V. Plant extracts to control ticks of veterinary and medical importance: a review. $S$ Afr J Bot 2016; 105: 178-193. http://dx.doi.org/10.1016/j.sajb.2016.03.010.

Akhtar Y, Pages E, Stevens A, Bradbury R, Camara CAG, Isman MB. Effect of chemical complexity of essential oils on feeding deterrence in larvae of the cabbage looper. Physiol Entomol 2012; 37(1): 81-91. http:// dx.doi.org/10.1111/j.1365-3032.2011.00824.x. 
Anthony JP, Fyfe L, Smith H. Plant active components: a resource for antiparasitic agents? Trends Parasitol 2005; 21(10): 462-468. PMid:16099722. http://dx.doi.org/10.1016/j.pt.2005.08.004.

Ashitani T, Garboui SS, Schubert F, Vongsombath C, Liblikas I, Pålsson $\mathrm{K}$, et al. Activity studies of sesquiterpene oxides and sulfides from the plant Hyptis suaveolens (Lamiaceae) and its repellency on Ixodes ricinus (Acari: Ixodidae). Exp Appl Acarol 2015; 67(4): 595-606. PMid:26385208. http://dx.doi.org/10.1007/s10493-015-9965-5.

Bagavan A, Kamaraj C, Elango G, Abduz Zahir A, Abdul Rahuman A. Adulticidal and larvicidal efficacy of some medicinal plant extracts against tick, fluke and mosquitoes. Vet Parasitol 2009; 166(3-4): 286292. PMid:19819626. http://dx.doi.org/10.1016/j.vetpar.2009.09.007.

Bennett GF. Oviposition of Boophilus microplus (Canestrini) (Acarida: Ixodidae). I. Influence of tick size on egg production. Acarologia 1974; 16(1): 52-61. PMid:4463680.

Castro KNC, Lima DF, Vasconcelos LC, Santos RC, Pereira AML, Fogaça FHS, et al. Composição química e eficácia do óleo essencial e do extrato etanólico de Alpinia zerumbet sobre Staphylococcus aureus. Arq Inst Biol (Sao Paulo) 2016; 83(1): 1-7. http://dx.doi.org/10.1590/18081657000192014

Castro-Janer E, Rifran L, Piaggio J, Gil A, Miller RJ, Schumaker TTS. In vitro tests to establish $\mathrm{LC}_{50}$ and discriminating concentrations for fipronil against Rhipicephalus (Boophilus) microplus (Acari: Ixodidae) and their standardization. Vet Parasitol 2009; 162(1-2): 120-128. PMid:19278787. http://dx.doi.org/10.1016/j.vetpar.2009.02.013.

Chagas ACS, Passos WM, Prates HT, Leite RC, Furlong J, Fortes ICP. Acaricide effect of Eucalyptus spp essential oils and concentrated emulsion on Boophilus microplus. Braz J Vet Res Anim Sci 2002; 39(5): 247-253. http://dx.doi.org/10.1590/S1413-95962002000500006.

Drummond RO, Ernst SE, Trevino JL, Gladney WJ, Graham OH. Boophilus annulatus and B. microplus: laboratory tests for insecticides. J Econ Entomol 1973; 66(1): 130-133. PMid:4690254. http://dx.doi. org/10.1093/jee/66.1.130.

Ellse L, Wall R. The use of essential oils in veterinary ectoparasite control: a review. Med Vet Entomol 2014; 28(3): 233-243. PMid:24147451. http:// dx.doi.org/10.1111/mve.12033.

Food and Agriculture Organization of the United Nations - FAO. Recommended methods for the detection and measurement of resistance of agricultural pests to pesticides. Tentative methods for larvae of cattle tick Boophilus spp. FAO Plant Prot Bull 1971; 19(7): 15-18.

Freitas DRJ, Pohl PC, Vaz IS Jr. Caracterização da resistência para acaricidas no carrapato Boophilus microplus. Acta Sci Vet 2005; 33(2): 109-117.

Galindo LA, Pultrini AM, Costa M. Biological effects of Ocimum gratissimum $\mathrm{L}$. are due to synergic action among multiple compounds present in essential oil. J Nat Med 2010; 64(4): 436-441. PMid:20559750. http://dx.doi.org/10.1007/s11418-010-0429-2.

Grisi L, Leite RC, Martins JRS, Barros ATM, Andreotti R, Cançado PHD, et al. Reassessment of the potential economic impact of cattle parasites in Brazil. Rev Bras Parasitol Vet 2014; 23(2): 150-156. PMid:25054492. http://dx.doi.org/10.1590/S1984-29612014042.

Hiltunen R, Holm Y. Essential oil of Ocimum. In: Hiltunen R, Holm Y, editors. Basil: the genus Ocimum. Amsterdam: Harwood Academic Publishers; 1999. p. 77-112.

Hocayen PA, Pimenta DS. Herbal extract against Rhipicephalus (Boophilus) microplus ticks. Rev Bras Plantas Med 2013; 15(4): 627-631. http://dx.doi. org/10.1590/S1516-05722013000500001.
Honório VG, Bezerra J, Souza GT, Carvalho RJ, Gomes-Neto NJ, Figueiredo RC, et al. Inhibition of Staphylococcus aureus cocktail using the synergies of oregano and rosemary essential oils or carvacrol and 1,8-cineole. Front Microbiol 2015; 6: 1223. PMid:26579115. http:// dx.doi.org/10.3389/fmicb.2015.01223.

Hüe T, Cauquil L, Fokou JBH, Dongmo PMJ, Bakarnga-Via I, Menut C. Acaricidal activity of five essential oils of Ocimum species on Rhipicephalus (Boophilus) microplus larvae. Parasitol Res 2015; 114(1): 91-99. PMid:25300420. http://dx.doi.org/10.1007/s00436-014-4164-6.

Leite RC. Boophilus microplus (Canestrini, 1887): susceptibilidade, uso atual e retrospectivo de carrapaticidas em propriedades das regióes fisiogeográficas da baixada do Grande-Rio e Rio de Janeiro, uma abordagem epidemiológica. [tese]. Itaguaí: Universidade Federal Rural do Rio de Janeiro; 1988 [cited 2007 Jan 12]. Available from: http://r1.ufrrj.br/wp/ppgcv/wp-content/ themes/PPGCV/pdf/R094.pdf

López MD, Pascual-Villalobos MJ. Mode of inhibition of acetylcholinesterase by monoterpenoids and implications for pest control. Ind Crops Prod 2010; 31(2): 284-288. http://dx.doi.org/10.1016/j.indcrop.2009.11.005.

Macedo IT, Oliveira LM, Camurça-Vasconcelos AL, Ribeiro WL, Santos JM, Morais SM, et al. In vitro effects of Coriandrum sativum, Tagetes minuta, Alpinia zerumbet and Lantana camara essential oils on Haemonchus contortus. Rev Bras Parasitol Vet 2013; 22(4): 463-469. PMid:24473869. http://dx.doi.org/10.1590/S1984-29612013000400004.

Mills C, Cleary BJ, Gilmer JF, Walsh JJ. Inhibition of acetylcholinesterase by tea tree oil. J Pharm Pharmacol 2004; 56(3): 375-379. PMid:15025863. http://dx.doi.org/10.1211/0022357022773.

Muhammad G, Naureen A, Firyal S, Saquib M. Tick control strategies in dairy production medicine. Pak Vet J 2008; 28(1): 43-50.

National Institute of Standards and Technology - NIST. Mass spectral library (NIST/EPA/NIH). Gaithersburg; 2011 [cited 2007 Jan 12]. Available from: http://webbook.nist.gov/chemistry/

Nazzaro F, Fratianni F, De Martino L, Coppola R, De Feo V. Effect of essential oils on pathogenic bacteria. Pharmaceuticals 2013; 6(12): 1451-1474. PMid:24287491. http://dx.doi.org/10.3390/ph6121451.

Oliveira PR, Bechara GH, Denardi SE, Nunes ET, Camargo-Mathias MI. Morphological characterization of the ovary and oocytes vitellogenesis of the tick Rhipicephalus sanguineus (Latreille, 1806) (Acari: Ixodidae). Exp Parasitol 2005; 110(2): 146-156. PMid:15888297. http://dx.doi. org/10.1016/j.exppara.2004.12.016.

Oliveira PR, Castro KNC, Anholeto LA, Camargo-Mathias MI. Cytotoxic effects of extract of Acmella oleraceae (Jambú) in Rhipicephalus microplus females ticks. Microsc Res Tech 2016; 79(8): 744-753. PMid:27271726. http://dx.doi.org/10.1002/jemt.22693.

Oliver JH Jr. Biology and systematics of ticks (Acari: Ixodida). Annu Rev Ecol Syst 1989; 20(1): 397-430. http://dx.doi.org/10.1146/annurev. es.20.110189.002145.

Prates HT, Leite RC, Craveiro A, Oliveira AB. Identification of some chemical components of the essential oil from molasses grass (Melinis minutiflora Beauv.) and their activity against cattle-tick (Boophilus microplus). J Braz Chem Soc 1998; 9(2): 193-197. http://dx.doi.org/10.1590/S010350531998000200013.

Remedio RN, Nunes PH, Anholeto LA, Oliveira PR, Camargo-Mathias MI. Morphological effects of neem (Azadirachta indica A. Juss) seed oil with known azadirachtin concentrations on the oocytes of semiengorged Rhipicephalus sanguineus ticks (Acari: Ixodidae). Parasitol Res 
2015; 114(2): 431-444. PMid:25346198. http://dx.doi.org/10.1007/ s00436-014-4200-6.

Remedio RN, Nunes PH, Anholeto LA, Oliveira PR, Sá ICG, CamargoMathias MI. Morphological alterations in salivary glands of Rhipicephalus sanguineus ticks (Acari: Ixodidae) exposed to neem seed oil with known azadirachtin concentration. Micron 2016; 83: 19-31. PMid:26852009. http://dx.doi.org/10.1016/j.micron.2016.01.004.

Roditakis E, Roditakis NE, Tsagkarakou A. Insecticide resistance in Bemisia tabaci (Homoptera: Aleyrodidae) populations from Crete. Pest Manag Sci 2005; 61(6): 577-582. PMid:15712366. http://dx.doi. org/10.1002/ps.1029.

Rodríguez-Vivas RI, Alonso-Díaz MA, Rodríguez-Arevalo F, FragosoSanchez H, Santamaria VM, Rosario-Cruz R. Prevalence and potential risk factors for organophosphate and pyrethroid resistance in Boophilus microplus ticks on cattle ranches from the state of Yucatan, Mexico. Vet Parasitol 2006; 136(3-4): 335-342. PMid:16413971. http://dx.doi. org/10.1016/j.vetpar.2005.05.069.

Roma GC, Camargo-Mathias MI, Faria AU, Oliveira PR, Furquim KCS, Bechara GH. Morphological and cytochemical changes in synganglion of Rhipicephalus sanguineus (Latreille, 1806) (Acari: Ixodidae) female ticks from exposure of Andiroba oil (Carapa guianensis). Microsc Res Tech 2013; 76(7): 687-696. PMid:23625505. http://dx.doi.org/10.1002/jemt.22219.

Roma GC, Nunes PH, Oliveira PR, Remédio RN, Bechara GH, CamargoMathias MI. Central nervous system of Rhipicephalus sanguineus ticks (Acari: Ixodidae): an ultrastructural study. Parasitol Res 2012; 111(3): 12771285. PMid:22610445. http://dx.doi.org/10.1007/s00436-012-2962-2.
Rosado-Aguilar JA, Aguilar-Caballero A, Rodriguez-Vivas RI, BorgesArgaez R, Garcia-Vazquez Z, Mendez-Gonzalez M. Acaricidal activity of extracts from Petiveria alliacea (Phytolaccaceae) against the cattle tick, Rhipicephalus (Boophilus) microplus (Acari: Ixodidae). Vet Parasitol 2010; 168(3-4): 299-303. PMid:20042296. http://dx.doi.org/10.1016/j. vetpar.2009.11.022.

Roulston WJ, Schnitzerling HJ, Schuntner CA. Acetylcholinesterase insensitivity in the Biarra strain of the cattle tick Boophilus microplus, as a cause of resistance to organophosphorus and carbamate acaricides. Aust J Biol Sci 1968; 21(4): 759-767. PMid:5680996. http://dx.doi. org/10.1071/BI9680759.

Soares MAS, Penha TA, Araújo SA, Cruz EMO, Blank AF, Costa-Junior LM. Assessment of different Lippia sidoides genotypes regarding their acaricidal activity against Rhipicephalus (Boophilus) microplus. Rev Bras Parasitol Vet 2016; 25(4): 401-406. PMid:27982301. http://dx.doi. org/10.1590/s1984-29612016087.

Stone BF, Haydock KP. A method for measuring the acaricide-susceptibility of the cattle tick Boophilus microplus (Can). Bull Entomol Res 1962; 53(3): 563-578. http://dx.doi.org/10.1017/S000748530004832X.

Vendramini MCR, Camargo-Mathias MI, Faria AU, Bechara GH, Oliveira PR, Roma GC. Cytotoxic effects of andiroba oil (Carapa guianensis) in reproductive system of Rhipicephalus sanguineus (Latreille, 1806) (Acari: Ixodidae) semi-engorged females. Parasitol Res 2012; 111(5): 1885-1894. PMid:22797575. http://dx.doi.org/10.1007/s00436-012-3031-6. 